Different pyroclastic breccias and related deposits represent important petrogenetic indicators of the magmatic-stratigraphic and tectonic evolution of the Poços de Caldas Alkaline Complex (PAC), the largest in South America and one of the 10 largest such complexes worldwide. PAC is a Cretaceous subcircular volcanicsubvolcanic caldera within Precambrian basement rocks at the eastern border of the Paraná Basin exhumed by differential erosion. It comprises ultrabasic through intermediate alkaline igneous, pyroclastic, volcaniclastic and minor sedimentary and basement rocks; PAC-magmatism lasted from $\geq 92$ to $\sim 76$ Ma b.p.

The oldest breccias in the PAC W-NW sector are of extrusive ankaratrites. Abundant $\mathrm{CO}_{2}$-rich fluid discharge caused prominent vesiculation, hydraulic fracturing, brecciation and carbonatization of these lava flows. Different pyroclastic, mixed and reworked breccias formed successively during construction of the main regional volcano of miaskitic phonolites and nepheline syenites (with AI. of $0.85-1.15$, and giannettite as the most common raremetal silicate), phonolitic tuffs, mud and debris-flows, until caldera-collapse and emplacement of discontinuous phonolite ring-dikes.

Post-caldera-collapse breccias formed through more local magmatic-tectonic, volcaniclastic and hydrothermal events, with or without temporal and/or spacial superposition. Fragments of typical aphanitic, microporphyritic phonolites, which cut the former nepheline syenites as shallow-subvolcanic dikes, occur associated with carbonate rock, ankaratrite, phonolite, pyroxenite, peridotite, granitic basement and Paraná Basin sedimentary rock fragments in intrusive to extrusive breccias bearing phlogopite-booklets in the phonolitic, locally carbonatized or pyritized matrix; lateral and vertical granulometric grading and interlayering with phonolitic surges and tuffisites and carbonatite flows also occur. These breccias were intruded by phonolite dikes; possibly coeval agpaitic eudialite nepheline syenites (Pedra Balão and Morro do Serrote type) occur as regionally separated minor intrusions.

At the end of regional phonolite and nepheline syenite magmatism breccia pipes formed at foci of magmatic-phreatic explosions and suffered low-grade UTh-REE-Zr-F-Mo mineralization through strong potassic and pyritic hydrothermalism. Local carbonatization of these breccias suggests nearby carbonatite intrusions (Morro do Ferro type). Finally, at about $76 \mathrm{Ma}$, dikes of ultramafic ultrapotassic biotite lamprophyres with abun- dant upper mantle xenoliths intruded the breccia pipes. - (December 14, 2001 ) .

\section{ESKER-LIKE FEATURES IN THE ITARARÉ SUBGROUP (LATE PALEOZOIC), NORTHERN PARANÁ BASIN, BRAZIL*}

Marcos R. Araujo and José R. Canuto**

Instituto de Geociências, USP, São Paulo, SP.

Presented by Antonio C. Rocha-CAmpos

Sediments occurring as discontinuous domed, elongated forms, 50 to $200 \mathrm{~m}$ in length, 20 to $50 \mathrm{~m}$ in width, and about $20 \mathrm{~m}$ in thickness, showing intense deformation, under the Lapa sandstone, are interpreted as eskers.

Three facies have been recognized: a) conglomerate of rounded pebbles and boulders in a massive, poorly sorted sandy matrix, sometimes cross-bedded, with lineated and imbricated clasts indicating NW transport, with normally graded sandy layers fragments included. The conglomerates show $1 \mathrm{~m}$ in thickness and lenticular geometry; b) two types sandstones: the first one is medium to fine-graded, massive, sometimes cross-bedded, showing NW transport, in layers up to $80 \mathrm{~cm}$ thick with tabular geometry; the second one is medium to fine-graded, well sorted, massive, sometimes showing gradacional stratification, with thicknesses of 10 to $20 \mathrm{~cm}$; c) massive tabular diamictite, of decimetric thickness, silty-sandy matrix with dispersed clasts, intercalated and interfingered in the base of its layers with sands and conglomerates and with sandstones in its tops. The layers are in a vertical way and deformed, and parallel to the direction of the channel of the Lapa sandstone.

The basal contact of the ruditic succession is erosional on older shales, while the upper contact also erosional, defines the base of the Lapa sandstone.

The glacial context of the time suggested that the sandstones and conglomerates were deposited by fluvioglacial processes and the diamictites (cohesive debris flows) flowed from the channel walls and interfingered with the sandstones and conglomerates.

The first phase of deformation caused folding with the differential melting of underlying ice below the sediments. Later, the total collapse of the sedimentary stack, due to melting of still existing ice in some parts, associated with the unstable settling of the sediments caused by the previously differential melting, would have led to a second deformation phase, facilitated by the still plastic state of the sediments, resulting in the refolding of the 
first phase folds. Deformation by compaction is rejected because the overlying Lapa sandstone is not deformed.

The above features suggest that the sediments correspond to an esker. The deposit is part of the lowstand system tract of the $3^{\text {rd }}$ order sequence $S_{2}$ described by Canuto et al. (2001). - ( December 14, 2001 ) .

\footnotetext{
* Supported by FAPESP, No. 97/13973-2.

**E-mail: jrcanuto@usp.br
}

THE THIRD ORDER SEQUENCE STRATIGRAPHY OF THE ITARARÉ SUBGROUP (LATE PALEOZOIC) ACROSS PARANÁ BASIN*

José R. CANuto**, PAulo R. SAntos AND

Antonio C. Rocha-CAMPoS

Instituto de Geociências, USP, São Paulo, SP.

The Itararé Subgroup (late Paleozoic) on the eastern margin of the Paraná Basin is subdivided into seven $50-80 \mathrm{~m}$ thick, type I, third order sequences that correspond to fining-coarsening upward cycles. Sequences are bounded at base by an erosional unconformity that at the eastern margin of the basin is marked either by glacially striated and/or glaciotectonised bedrock, or intraformational, glacially striated surfaces.

Our depositional model considers that each erosional surface, usually overlain by subglacial tillite, records an advance of a grounded glacier. Higher up the glaciogenic section includes glacioterrestrial, glaciomarine and marine beds (tillites, flow diamictites, proglacial rhythmites with dropstones, outwash sandstone, etc.), deposited during retreat of the ice margin. The sequences culminate with marine shale documenting short-lived post-glacial transgression, and shallow-marine progradacional fluviatile-deltaic sandstone, associated to glacioisostatic rebound that followed retreat of the glacial margin.

This type of sequence was earlier identified in outcrop and is now recognized in the subsurface of the Paraná Basin, along an east-west cross-section trough wells 1-PT1PR, 1-RO-1-PR, 2-NA-1-PR and AMst-1-MT in Brazil, and Asunción 2 in Paraguay. Correlation of sequences in subsurface and outcrop was established lithostratigraphically from top to bottom, with reference to a datum represented by a widespread marine marker bed intercalated in the Rio Bonito Formation. Absence of basal S1 sequence in well 1-RO-1-PR may be related to its location on a basement high. Only the uppermost part of S1 is recorded in well AMst-1-MT due to the intercalation of a thick diabase sill (Cretaceous) between Itararé beds and the underlying Ponta Grossa Formation.

With exception of the two cases, the subsurface section shows a full sequential correspondence. Most sequences, however, thicken from SE-NW, almost doubling values found on the eastern margin of the Paraná Basin. This suggests higher subsidence rate towards west, that compensated the positive tectonic behavior of the adjacent Asunción arch and created adequate space to accommodate sediments supplied from the eastern flank of the Asunción arch. - (December 14, 2001 ) .

\footnotetext{
* Supported by FAPESP 97/13973-2.

**E-mail: jrcanuto@usp.br
}

\section{EXTRUSION-RELATED EXTENSIONAL SIGNATURES UNDER HIGH-PRESSURE NAPPE COMPRESSIONAL REGIME*}

Carlos H. G. Carvalho and Mario C. Campos-Neto

Instituto de Geociências, USP, São Paulo, SP.

Presented by Antonio C. Rocha-CAmpos

The Neoproterozoic nappe system exposed south of the São Francisco Craton underwent a minimum of $200 \mathrm{~km}$ of near-horizontal northeastward displacement. This nappe system comprises the south-southeast sector of Brasília Belt and piles up three tectonic settings (from top to bottom): the roots of a neoproterozoic magmatic arc (Socorro-Guaxupé Nappe); high-pression metassedimentary nappes (Três Pontas-Varginha, Carmo da Cachoeira, Aiuruoca-Andrelândia, Pouso Alto and Carvalhos klippe); parautochthonous medium-pressure nappes and duplexes.

In the southeast of Aiuruoca-Andrelândia Nappe, a brittle-ductile sinistral shear zone (Liberdade Shear Zone) limits the southern Alagoa Migmatites and may represent a lateral ramp for the eastern Lima Duarte Nappe. Close to Alagoa (MG), this shear zone turns E-W, breaking the nappe hind portion, in a southward normal-ductile movement.

North of this shear zone, the garnet-sillimatite bearing metassedimentary sequence lays over a gnaissicdiatexitic basement and is highly sliced by strata-like tourmaline-bearing granites. In the metassediments, main foliation $S_{2}$ is transposed by a normal-fault related thick protomilonitic $S_{2}$ ' foliation. In the gnaisses, southward transport is marked by shear-sense indicators such as S-C foliations and quartz sigmoids. A low-temperature, late brittle thrust system, overlaps the extensional structures.

Heading north, the end of this structural- 